\title{
Biskup jako następca apostołów: spojrzenie metropolity Syberyjskiego Ignacego (Rimskiego-Korsakowa)
}

\author{
ks. Iwan Nikulin \\ Katedra Historii Instytutu Misyjnego \\ Katedra Nauk Kościelno-Historycznych i Humanistycznych Seminarium Duchownego w Jekaterynburgu \\ nikulinivan@yandex.ru
}

\begin{abstract}
Rev. Ivan Nikulin, A Bishop as a Successor of the Apostles: Point of view of the Siberian Metropolitan Ignatius (Rimsky-Korsakov), Elpis, 16 2014: 95-98.

священник Иван Александрович Никулин, Архиерей как приемник апостолов: взгляд сибирского митрополита Игнатия (Римского-Корсакова), Elpis, 16 2014: 95-98 .
\end{abstract}

\begin{abstract}
This article presents the perception of ministry of the known church leader and writer of the last part of the 17th century, Bishop Ignatius (Rimsky-Korsakov), Metropolitan of Tobolsk. The Siberian is considered on the basis of a wide range of materials, including unpublished sources. He understood his work as a continuation of the Apostles, and tried to express his work externally in apostolic form, in particular in travelling throughout the diocese and sending letters.

Streszczenie: W artykule na podstawie szerokiego kręgu, w tym również niepublikowanych wcześniej, źródeł rozpatruje się postrzeganie swojej posługi przez znanego działacza kościelnego i pisarza ostatniego trzydziestolecia XVII wieku biskupa Ignacego (Rimskiego -Korsakowa), metropolitę Tobolskiego i Syberyjskiego. Rozumiał on swoją działalność jako kontynuator apostołów i próbował nadać wielu swym działaniom zewnętrznie formę apostolską, w szczególności wyrażało się to w jego podróżach po diecezji i rozsyłaniu listów.

Аннотация: В статье на основании широкого круга, в том числе неопубликованных источников рассматривается восприятие своего служения известным церковным деятелем и писателем последней трети XVII века преосвященным Игнатием (Римским-Корсаковым), митрополитом Тобольским и Сибирским. Он понимал свою деятельность как продолжатель апостолов, и старался многим своим действиям придать внешне форму апостольских, что в частности выразилось в путешествиях по епархии и рассылке посланий.
\end{abstract}

Keywords: Ignatius (Rimsky-Korsakov), Tobolsk diocese, episcopal ministry

Kluczowe słowa: Ignacy (Rimski-Korsakow), diecezja Tobolska, posługa biskupia

Ключевые слова: Игнатий (Римский-Корсаков), Тобольская епархия, архиерейское служение

We współczesnej nauce historycznej dużego znaczenia nabiera wymiar antropologiczny lub „historie osobowości", jednym z aspektów którego może być badanie postrzegania przez "bohatera” swoich działań i samego siebie. Analiza rozumienia przez biskupa jego posługi, postrzegania siebie samego jest bardzo ważna nie tylko dla historii idei chrześcijańskiej, ale także dla oceny działalności samych biskupów.

Myśl chrześcijańska zawsze postrzegała biskupów jako następców apostołów, jednak realizacja tego „apostolstwa" w działalności konkretnego biskupa nie jest pozbawiona, naszym zdaniem, pewnego interesu chociażby dlatego, że teologia Kościoła prawosławnego XVII wieku jest jeszcze nie wystarczająco zbadana. W tym sensie, bardzo oryginalnie, w pewnym stopniu niestandartowo, postrzegał swoją biskupią posługę znany kościelny działacz, pisarz i myśliciel ostatniego trzydziestolecia XVII wieku, metropolita Syberyjski i Tobolski Ignacy (Rimski-Korsakow). Data urodzenia i jego świeckie imię nie są znane. Pochodził on ze znanego moskiewskiego, szlacheckiego rodu - Korsakowych, którzy w latach 80 - tych XVII wieku dobili się uzyskania przystawki i stali się Rimskimi-Korsakowymi. Najprawdopodobniej przyjął on święcenia mnisze w Pustelni Krestomarowskiej, a następnie, przez krótki czas był ekkleziarch $q^{1}$ w Monasterze Sołowieckim (16771680). W 1684 roku zostaje archimandrytą carskiego Monasteru Nowospasskiego i zaczyna brać aktywny udział we wszystkich wydarzeniach kościelno-politycznych tego okresu. Aktywny wojownik z łacińskimi i protestanckimi wpływami w Moskwie, zwolennik partii grekofilskiej, ideolog Moskiewskiego carstwa, współpracownik patriarchy Joachima, zostawił znaczący ślad i jako wojownik ze staroobrzędowcami na Syberii. Po śmierci patriarchy Joachima, w 1692 roku Ignacy został nominowany na biskupa diecezji Tobolskiej².

Po raz pierwszy próbę zbadania postrzegania przez metropolitę Ignacego jego posługi podjęła O. D. Żurawiel'3, która na podstawie analizy Żywotu Symeona Wierchoturskiego pierwsza wyraziła pogląd, że „Ignacy zestawiał

Ekkleziarcha - mnich odpowiedający w klasztorze za przebieg nabożeństwa.

2 Dokładna bibliografia prac poświęconych metropolicie Ignacemu zob.: I. A. Nikulin, Ignatij (Rimski-Korsakow), mitr.[w:] Prawosławnaja enciklopedija, Tom 21, Moskwa 2009, s. 125-127.

3 O. D. Żurawiel, Żytije Simeona Wierchoturskogo (k izuczeniju literaturnogo tworczestwa Ignatija Rimskogo-Korsakowa) [w:] Istoczniki po russkoi istorii i literature: sredniowiekowije i nowoje wremia, Nowosybirsk 2000, s. 73-93. 
własną działalność na Syberii z posługą apostolskąa". Aby udowodnić tę tezę, przywiodła ona cały szereg argumentów, opierając się przede wszystkim na Żywocie sprawiedliwego Symeona. Naszym zdaniem, badania w tym kierunku należy kontynuować, wykorzystując i inne dzieła biskupa tobolskiego, a także analizę jego działalności ${ }^{5}$.

Rozumienie przez metropolitę Ignacego swojej posługi można określić analizując jego dzieła napisane w diecezji Tobolskiej. To przede wszystkim dzieła literackie: „Posłania na armen i poluarmen” (ros. „Послания на армен и полуармен") 6 napisane między 1693 i 1696 rokiem;. List do Pekinu (1695 rok), List do Krasnojarska (1697 rok); Żywot Symeona Wirchoturskiego (po 1695 roku). Najciekawsze, pod tym względem, są fragmenty dzieł, w których biskup mówi o sobie.

Większość takich fragmentów zawiera Żywot Symeona Wierchoturskiego. Zimą 1694-1695 roku metropolita odbył „podróż” do miast zachodniej Syberii (TobolskTiumeń-Turyńsk-Piełym-Wierchoturie-Irbit-Tobolsk), podczas którego miało miejsce zbadanie relikwii świętego sprawiedliwego Symeona Wierchoturskiego. Najwyraźniej, jeszcze w czasie podróży prowadził on zapiski podróżne, które w krótkim czasie zostały pomieszczone w tzw. „Żywocie sprawiedliwego Symeona Wierchoturskiego", który jest $w$ istocie opowieścią o odnalezieniu relikwii. Głównym bohaterem Żywotu staje się sam autor, metropolita Ignacy, i narracja wiedziona jest w pierwszej osobie. Nie można nie zgodzić się z O. D. Żurawiel, że „opowieść o świętym przedstawiona jest jak słowo o rozpowszechnieniu Ewangelii w kraju Syberyjskim”. „Obraz Symeona Wierchoturskiego przedstawiony jest w Żywocie w związku z tematem oświecenia Syberii, a więc i działalności Ignacego jako głowy Syberyjskiej metropolii”". O. D. Żurawiel przekonująco udowodniła, że podróż opisana w Żywocie przeplata się z opisem podróży apostołów. Autor opisuje swoją podróż, której celem jest właśnie „głoszenie świętej Ewangelii”, wymieniając miasta i wsie, które odwiedza.

Warto zwrócić uwagę na cele, które stawiał biskup i przy planowaniu „podróży” do „wschodnich miast” diecezji Syberyjskiej (która nigdy nie miała miejsca). Zwracając się do Syberyjskiego Prikazu, pisze: „Zostało mi powierzone, panowie, orędownikowi waszemu przed Bogiem, to wielkie dzieło - głoszenia świętej Ewangelii. Powinnienem to wypełniać i prawidłowo przekazywać słowo Prawdy, co więcej, dbać o dobre nauczanie przed Bogiem dla poprawienia spraw kościelnych tutejszego Syberyjskiego carstwa, dla utwierdzenia naszej chrześcijańskiej, prawosławnej, katolickiej wiary”. I na końcu dodaje: „I ja, orędownik wasz,...

Pierwsze próby analizy dannego problemu zob.: I. A. Nikulin, Mitropolit Tobolskij i Sibirskij Ignatij (Rimski-Korsakow): wosprijatije swojego służenija apchijerejem konca XVII w. [w:] Uralskij istoriczeskij wiestnik, nr 3 (36), Jekaterynburg 2012, s. 24-30.

6 Armenami biskup Ignacy nazywa staroobrzędowców.

7 O. D. Żurawiel, Żytije Simeona Wierchoturskogo..., s. 91.

8 Tamże, s. 88.

9 Rosyjskie Państwowe Archiwum Akt Dawnych - RPAAD, (Российский государственный архив древних актов (РГАДА)), Fond 214, Spis 3, Kolumna 1058, Arkusz 16.
}

Syberyjski kraj, choć z pomocą Bożą od tej naśladowanej, staroobrzędowej herezji oczyścić i czyste postanowienia i dogmaty świętego, soborowego i apostolskiego Kościoła utwierdzić pragnę, waszym carskim postanowieniem, przygotowuję się do podróży dla potwierdzenia świętego nauczania i dogmatów Kościoła" ${ }^{10}$. W drugim posłaniu do Prikazu Syberyjskiego, pisze: „Pisałem ja, orędownik wasz, do was, wielkich władców, ... o mojej podróży do waszej wielkich władców ojcowizny, do miast wschodniej Syberii, do wręczonego mi stada, ... dla głoszenia świętej Ewangelii, i dla potwierdzenia świętej, prawosławnej, chrześcijańskiej wiary i zniszczenia naśladowców armnenskogo (staroobrzędowego) nauczania, i dla założenia świątyń w miejscach rozpowszechnienia dannego rozłamu dla zbawienia prawosławnych chrześcijan i dla budowy i konsekracji świętych, Bożych kościołów"11. Tak więc, głównym celem planowanej podróży do „wschodnich miast” Syberii dla metropolity było głoszenie świętej Ewangelii, wzmocnienie wiary prawosławnej i dogmatów (tzn. nauczania Kościoła), walka z rozłamem i założenie nowych kościołów.

I kto wie, czy jeśliby „podróż” do „wschodnich miast” Syberii miałaby miejsce, nie dostałaby ona od metropolity nazwy „drugiej podróży” (jak wiadomo u apostoła Pawła były cztery podróże misyjne).

Jak było powiedziane wyżej, w latach 1694-95 metropolita Ignacy objeżdża część swojej diecezji (część zachodniej Syberii). Analizując Żywot Symeona Wierchoturskiego można, nieco umownie, określić schemat odwiedzania zamieszkałych punktów. Na wjeździe do miasta lub wsi metropolitę najczęściej witały władze lokalne wraz z duchowieństwem i ludem. Biskup błogosławił wszystkich i, być może, mówił pouczenie. Często metropolita z rana odprawiał Boską Liturgię, po której obowiązkowo wygłaszał kazanie, które sądząc po Żywocie miało charakter katechetyczny. Biskup starał się przedstawić swoim słuchaczom podstawy historii biblijnej, historii Kościoła, nauczania kościelnego, itd. Możemy przypuszczać, że takie kazania były długie.

Tak więc, pierwszym kierunkiem swojej działalności metropolita widział podróże po diecezji, głoszenie Słowa Bożego. I w tym wyraźnie widoczne jest jego naśladowanie działalności apostołów, a autor Żywotu Symeona Wierchoturskiego, jak zostało już powiedziane, w narracji wydarzeń wzoruje się na Księdze Dziejów Apostolskich.

Należy zauważyć, że w XVII wieku biskupi odbywali podróże po swojej diecezji głównie w celu konsekracji nowo wybudowanych kościołów. Objazd diecezji był wydarzeniem wyjątkowym, wymagał błogosławieństwa patriarchy i carskiego pozwolenia. Co ciekawe, sytuacja zmienia się całkowicie na początku XVIII wieku, w dużej mierze zgodnie z ideami, które były charakterystyczne i dla biskupa Ignacego. W „Regulaminie duchownym” (wydanym w 1721 roku) stwierdza się: „biskupowi przystało raz na rok lub raz na dwa lata objechać i odwiedzić swoją diecezję. I jest tego, oprócz wielu innych (przyczyn - autor), wielki obraz Pawła

\footnotetext{
10 Tamże, Arkusz 18.

11 RPAAD, Fond 214, Spis 3, Kolumna 1058, Arkusz 15.
} 
apostoła, który jawi się w Dziejach...."12. Oprócz katechizacji, oczywiście, głównym celem podróży, zgodnie z „Regulaminem duchowym", jest nadzór nad życiem diecezjalnym.

Podtrzymując tezę O. D. Żurawiel o szczególnym postrzeganiu przez metropolitę swej podróży, należy zwrócić uwagę na jeszcze jeden kierunek działalności biskupa tobolskiego, który był również zestawiany przez niego z działalnością apostołów, dokładniej z ich dziedzictwem piśmienniczym.

Już w pierwszym roku przebywania na Syberii metropolita zwrócił się do swego stada z pierwszym „posłaniem na armen i połuarmen". Większość swoich listów autor zaczyna i kończy fragmentami z Listów Apostolskich, często nie oznaczając ich jako cytaty, a „wplatając” je w początek i koniec swojego autorskiego tekstu, co zwiększa jego podobieństwo do Listów Apostolskich. Wszystkie posłania, z wyjątkiem „trzeciego" na „armen i połuarmen”, jeśli chodzi o ich formę, można odnieść do Listów Apostolskich. Wszystkie są skierowane do konkretnego kościoła, czy to „Syberyjskiego”, „Krasnojarskiego” lub do „wszystkich prawosławnych chrześcijan, zamieszkających w Królestwie Chińskim". Chociaż napisane są w związku z konkretnymi historycznymi wydarzeniamiami, mają na celu realizację bardziej odległych celów. W swych listach biskup Ignacy używa charakterystycznych dla Listów Apostolskich zwrotów, „,bracia”, , ,umiłowani”, „dziecko i współpracownik”, itd.

Przytoczymy konkretne przykłady z Listu do Pekinu ${ }^{13}$. Wstęp, praktycznie w całości, jest parafrazą początkowej części Listu apostoła Pawła do Koryntian. Na początku metropolita zwraca się nie tylko do o. Maksyma, ale do „wszystkich prawosławnych chrześcijan, zamieszkujących w Królestwie Chińskim" i błogosławi ich. Następnie autor dziękuje Bogu „za łaskę Bożą, daną wam w Chrystusie Jezusie" i pisze, że prawosławni, znajdujący się w Chinach, pomimo niewoli, zostali wzbogaceni „we wszelkie słowo i wszelkie poznanie", jasno dając do zrozumienia, że ich duchowym bogactwem jest działalność misyjna (świadectwo Chrystusowe), dlatego, aby być czystymi („bez zarzutu”) w dzień Pana naszego Jezusa Chrystusa.

\begin{tabular}{|c|c|}
\hline Tekst Listu & 1 List do Koryntian, 1-12 \\
\hline $\begin{array}{l}\text { Z Bożej łaski, Jego Ekscelencja } \\
\text { Ignacy, biskup Tobolski i całej Sy- } \\
\text { berii metropolita. } \\
\text { W Duchu Świętym synowi } \\
\text { i współpracownikowi naszemu } \\
\text { pokornemu, głosicielowi świętej } \\
\text { Ewangelii w Królewstwie Chińs- } \\
\text { kim, nabożnemu kapłanowi Ma- } \\
\text { ksymowi Leontiewowi i wszyst- } \\
\text { kim prawosławnym chrześcija- } \\
\text { nom, zamieszkującym w Królew- } \\
\text { stwie Chińskim, błogosłowieństwo } \\
\text { biskupie. }\end{array}$ & $\begin{array}{l}\text { Paweł, z woli Bożej powołany } \\
\text { na apostoła Jezusa Chrystusa, i So- } \\
\text { stenes, brat, do Kościoła Bożego w } \\
\text { Koryncie, do tych, którzy zostali } \\
\text { uświęceni w Jezusie Chrystusie } \\
\text { i powołani do świętości wespół } \\
\text { ze wszystkimi, którzy na każdym } \\
\text { miejscu wzywają imienia Pana } \\
\text { naszego Jezusa Chrystusa, ich i na- } \\
\text { szego [Pana]. }\end{array}$ \\
\hline
\end{tabular}

12 Duchownyj reglament, Moskwa 1856, s. 40.

13 Dokładniej zob.: I. A. Nikulin, Gramota $w$ Pekin swiaszczenniku Maksimu Leontiewu mitropolita Ignatija (Rimskogo-Korsakowa) kak pamiatnik literatury konca XVII w. [w:] Wiestnik Jekaterinburgskoj duchownoi seminarii, nr 2, Jekaterynburg 2011, s. 206-221.
Łaska wam i pokój od Boga Ojca naszego, i od Pana Jezusa Chrystusa i Świętego Życiodajnego Ducha.

Bogu mojemu dziękuję wciąż za was, za łaskę dana wam w Chrystusie Jezusie. W Nim to bowiem zostaliście wzbogaceni we wszystko, chociaż jesteście w niewoli, we wszelkie słowo $i$ wszelkie poznanie, bo świadectwo Chrystusowe utrwalito sie $w$ was, tak iz nie brakuje wam żadnego daru łaski, gdy oczekujecie objawienia się Pana naszego Jezusa Chrystusa. On też będzie umacniat was aż do końca, abyście byli bez zarzutu $w$ dzień Pana naszego Jezusa Chrystusa. Wierny jest Bóg, który powołał nas do wspólnoty, która jest w chrzcie świętym $z$ Synem swoim Jezusem Chrystusem, Panem naszym.

A przeto upominam was, bracia $w$ imię Pana naszego Jezusa Chrystusa, abyście żyli wszyscy w prawosławnej, chrześcijańskiej wierze, abyście wierzyli w Ojca i Syna i Ducha Świętego, którego chwalą w trzech hipostazach, sławią pieśniami w jedności Boga.

Słyszałem od nabożnych kupców, którzy chodzili do was, do Chin, że dzięki woli Bożej chiński władca Bogdyhanowo Wysoczestwo dał wam swobodę wyznawania świętej, prawosławnej, chrześcijańskiej wiary... ${ }^{1}$

I. A. Nikulin, Gramota w Pekin swiaszczenniku Maksimu Leontiewu mitropolita Ignatija (Rimskogo-Korsakowa) kak pamiatnik literatury konca XVII w, s. 217.

Cyt. za: Pismo Święte Starego i Nowego Testamentu, Wydawnictwo Pallottinum, Poznań 2010.

Należy zwrócić uwagę i na fakt, że w rękopisach „postania na armen i potuarmen", utworzonych w Tobolskim domu biskupim, listy mają nagłówki: „pierwszy list”, „drugi list" $i$,trzeci list" ${ }^{\prime \prime}$. Tytuły te zostały wyraźnie napisane z polecenia autora, ponieważ rękopisy posiadają autografy metropolity Ignacego. Takie tytuły współbrzmią z numeracją porządkową Listów Apostolskich, na przykład „Pierwszy List świętego Jana”, „Drugi List świętego Jana”, itd. Wynika $\mathrm{z}$ tego, że wszystkim swoim listom biskupim metropolita świadomie nadaje formę apostolskich, pozycjonując siebie w ten sposób apostołem Syberii.

Z wszystkiego powiedzianego wyżej możemy wyciągnąć następujące wnioski. Podtrzymując teżę O. D. Żurawiel, należy stwierdzić, że biskup Ignacy bardzo wyraźnie widzi siebie następcą posługi apostolskiej. To „naśladownictwo" wyraża się w dwóch głównych kierunkach. W pierwszej kolejności, jest to wykorzystywanie doświadczenia podróży apostołów. Przy czym, cele tych podróży $\mathrm{w}$ dużej mierze pokrywają się z tymi zadaniami, które stawiali apostołowie. Właśnie takiemu rozumieniu swojej po-

14 Rosyjska Nacjonalna Biblioteka, Zbiór Sankt-Petersburgskiej Akademii Duchownej, nr 164; Rosyjska Nacjonalna Biblioteka, Zbiór Monasteru Sołowieckiego, nr 663/721. 
sługi można przypisać uporczywość w próbie podróży do wschodniej Syberii. Oprócz tego, takie zestawienie wyraża się w zwracaniu się do swego stada za pomocą specjalnych listów. Biskup Ignacy celowo tworzy swoje listy podobnymi do Listów Apostolskich, celowo przeplata swoje słowa i słowa apostołów.

Analizując postrzeganie przez metropolitę samego siebie jako „apostoła”, należy zauważyć, że w pierwszej kolejności zapożycza on formy zewnętrzne. W „podróży” po Syberii, w przeciwieństwie do apostołów, towarzyszył mu liczny orszak ${ }^{15}$. Naśladowanie apostołów nie przywiodło go ku myśli o potrzebie poszukiwania ewangelicznego ubóstwa, przeciwnie, metropolita starał się rozszerzyć posiadłości ziemskie i zwiększyć bogactwo diecezji Tobolskiej ${ }^{16}$. Losy syberyjskiego „naśladowcy apostołów” złożyły się nie prosto. Tak i niezrozumiany na Syberii, przeżywszy ostry konflikt z wojewodami tobolskimi, którzy nie pozwolili mu odwiedzić wschodniej części Syberyjskiej diecezji, pod koniec 1699 roku udał się do Moskwy, gdzie pokłóciwszy się

\footnotetext{
15 Wojewodowie tobolscy wydzielili biskupowi 50 wozów dla odbycia podróży. Zob.: RPAAD, Fond 214, Spis 3, Kolumna 1058, Arkusz 21.

16 RPAAD, Fond 214, Spis 3, Kolumna 1277; Polnoje sobranije zakonow Rossijskoj imperii c 1649 goda, Tom 3, Sankt-Petersburg 1830, s, 234-215.
}

z patriarchą Adrianem, zmarł przeszedłszy w stan spoczynku w Klasztorze Simonowym w 1701 roku.

Trudno powiedzieć, czym był sformułowany taki stosunek Ignacego do swej posługi. Być może, właściwościami jego charakteru i przekonaniem, że było mu przygotowane specjalne przeznaczenie. Być może, jego przedstawieniami o wyjątkowości misji jakiegokolwiek biskupa, który okazał się na służbie w nieobjętej, wieloetnicznej Syberii. Wątpliwym jest, że było to podyktowane kościelną i państwową regulacją działalności syberyjskich metropolitów. Niestety, zachował się jedynie ukaz biskupowi Syberyjskiemu Makaremu z 1625 roku, który daje nam przedstawienie o tych obowiązkach, które nakładały władze moskiewskie na syberyjskich hierarchów. Dość zwięźle stwierdza się w nim: „Pouczać cały lud, aby żył $\mathrm{w}$ wypełnianiu prawa chrześcijańskiego, według przykazań Bożych i Świętych Apostołów i Ojców Świętych"17. Widocznie, zakładano, że formę i metody katechezy każdy biskup wybiera sam.

Tobolskij archijerejskij dom w XVII wiekie, Nowosybirsk 1994, s. 213-215.

\section{Bibliografia}

\section{Źródła archiwalne}

Rosyjskie Państwowe Archiwum Akt Dawnych - RPAAD, (Pocсийский государственный архив древних актов (РГАДА)): Fond 214, Spis 3, Kolumna 1058, Arkusze 15, 16, 18, 21.

Rosyjska Nacjonalna Biblioteka:

Zbiór Sankt-Petersburgskiej Akademii Duchownej, nr 164.

Zbiór Monasteru Sołowieckiego, nr 663/721.

\section{Opracowania}

Pismo Święte Starego i Nowego Testamentu, Wydawnictwo Pallottinum, Poznań 2010.

Polnoje sobranije zakonow Rossijskoj imperii c 1649 goda, Tom 3, Sankt-Petersburg 1830.

Tobolskij archijerejskij dom w XVII wiekie, Nowosybirsk 1994.

Nikulin I. A., Gramota w Pekin swiaszczenniku Maksimu Leon- tiewu mitropolita Ignatija (Rimskogo-Korsakowa) kak pamiatnik literatury konca XVII w. [w:] Wiestnik Jekaterinburgskoj duchownoi seminarii, nr 2, Jekaterynburg 2011, s. 206-221.

Nikulin I. A., Ignatij (Rimski-Korsakow), mitr.[w:] Prawosławnaja enciklopedija, Tom 21, Moskwa 2009.

Nikulin I. A., Mitropolit Tobolskij i Sibirskij Ignatij (RimskiKorsakow): wosprijatije swojego stużenija apchijerejem konca XVII w. [w:] Uralskij istoriczeskij wiestnik, nr 3 (36), Jekaterynburg 2012, s. 24-30.

Duchownyj reglament, Moskwa 1856.

Żurawiel O. D., Żytije Simeona Wierchoturskogo (k izuczeniju literaturnogo tworczestwa Ignatija Rimskogo-Korsakowa) [w:] Istoczniki po russkoi istorii i literature: sredniowiekowije i nowoje wremia, Nowosybirsk 2000, s. 73-93. 